\title{
Water quality index and pollution loading capacity of Setu Babakan, Jakarta-Indonesia
}

\author{
Arina Khofiyanida and Margaretha Widyastuti* \\ Department of Environmental Geography, Faculty of Geography, Universitas Gadjah Mada, 55281 Yogyakarta Special Region \\ Indonesia
}

\begin{abstract}
Setu Babakan in the City of Jakarta Selatan contributes economically as a water tourist attraction. With its location in an urban area, growing human activities in its surroundings pose threats of contamination and reduction to its water quality. This research set out to analyze the water quality based on the Class II water quality standard issued in the Governmental Regulation No. 82 of 2001, determine the water quality index, and assess the pollution loading capacity of Setu Babakan. It drew on primary data collected by sampling water at four points in the inlet, middle, and outlet. The parameters observed were temperature, TDS, TSS, $\mathrm{pH}$, nitrate, phosphate, detergent, BOD, and COD, using the CCME method to determine the water quality index and the Regulation of the Minister of Environment No. 28 of 2009 to examine the pollutant loading capacity. The results showed that (1) the $\mathrm{pH}$, TSS, BOD, COD, phosphate, and detergents levels had exceeded the water quality standards, (2) the water quality index of Setu Babakan was categorized as marginal to fair, and (3) this body of water could no longer carry pollutant loads that contributed to TSS, $\mathrm{BOD}$, and COD accumulation.
\end{abstract}

\section{Introduction}

Water, a crucial part of natural resources to sustain the life of all living organisms, requires carefully planned concerted efforts to preserve and maintain its quality and quantity so that they can make good use of it $[1,2]$. Water quality assessment is, therefore, necessary in finding out whether or not a body of water can fulfill human needs, starting from drinking to other varying purposes, such as aquaculture, industry, and animal husbandry. For humans and other living beings, water can be straightforwardly extractable from surface water, including natural and artificial reservoirs locally called situ. Situ is the term used by the people of Jawa Barat to refer to a body of water that resembles a small lake [3].

Setu Babakan is situated in an urban area, precisely at Serengseng Sawah Subdistrict, Jagakarsa District, the City of Jakarta Selatan. Urban areas are known for their high population density, which may bring about pollution issues [4]. For instance, the majority of urban populations have unfortunately developed a behavior of discarding their refuses directly to the river, and there is a growing number in industrial estates that dispose of improperly treated wastes into the environment, introducing pollutants to waters [5]. Since contaminants can affect the overall quality of waters, human activities are often associated with the reduced usability of several bodies of water [6]. As for Setu Babakan, pollution threats are attributable to its location, which is in the center of a settlement area. Activities taking place in the surrounding households generate domestic waste that potentially affects its water quality. The development of residential buildings is responsible for high accumulations of pollutant loads and has, therefore, led to decreased capacities to self-purify [7]. Besides, ongoing aquaculture activities at this reservoir can be detrimental to water quality parameters as they alter the physical, chemical, and biological properties of the water. Uneaten fish food is likely to accumulate at the bottom of the lake and decompose with the help of microorganisms, producing toxic substances like ammonia, nitrite, and sulfur [8]. Pollution occurs if the observed parameters are above their respective threshold or outside the predetermined range published in relevant documents or legal products. At this state, the pollutant loading capacity has been exceeded, or the water quality status has turned into contaminated.

Setu Babakan is a water feature with an economic function, that is, as a water tourist attraction. However, substantial amounts of human activities around it potentially introduce contaminants into its water, modifying the quality and causing pollution. For these reasons, studies on its latest water quality and pollutant loading capacity become necessary so as to suppress the detrimental effects of physical development and maintain its function as a clean freshwater resource. Accordingly, this research attempted to (a) analyze the water quality based on the Class II water quality standard [9], (b) determine the water quality index, and (c) assess the pollutant loading capacity of Setu Babakan.

\footnotetext{
*Corresponding author: mwiwik@ugm.ac.id
} 


\section{Methods}

This research employed a survey method, that is, a data collection technique involving measurements in the field. Research variables, data acquisition methods, and data analyses are explained as follows.

The water quality data of Setu Babakan were measured directly in the field and further tested in the laboratory for these parameters: temperature, Total Dissolved Solid (TDS), Total Suspended Solid (TSS), pH, Biochemical Oxygen Demand (BOD), Chemical Oxygen Demand (COD), nitrate $\left(\mathrm{NO}_{3}\right)$, phosphate $\left(\mathrm{PO}_{4}\right)$, and detergents, with the Class II water quality standard as a reference for comparison [9]. This study, however, did not observe Dissolved Oxygen (DO) due to limitations in tools and instruments. The reservoir water was collected from around 08.00 until 11.00 am WIB (Western Indonesian Time) at four points determined with purposive sampling technique (namely: Inlet 1, Inlet 2, middle, and outlet of Setu Babakan) by following the guidelines proposed in [10], i.e., starting from the bottom to the water surface and the results are in composites. Due to a lack of permits from the site manager, the researchers were only able to collect one sample from the middle. Given that the CCME (Canadian Council Minister of the Environment) method requires a time-series data, the water sampling was carried out at four different times, namely August, October, and December 2019 and February 2020.
The water quality standard was determined using the CCME method and processed in the Water Quality Index (WQI) Calculator program. CCME is a mathematical approach that differentiates quality standards into five classes [11], as seen in Table 1.

Table 1. Categories of CCME WQI

\begin{tabular}{cc}
\hline Categories & CCME WQI Domain \\
\hline Excellent & $95-100$ \\
\hline Good & $80-94$ \\
\hline Fair & $65-79$ \\
\hline Marginal & $45-64$ \\
\hline Poor & $0-44$ \\
\hline
\end{tabular}

This classification operates on three factors, namely F1 (Scope), F2 (Frequency), and F3 (Amplitude). As described in the guidelines for the Canadian Water Quality Index 1.0 [11], the equations used to assess the CCME water quality index are presented below.

F1 (Scope): percentage of parameters exceeding the water quality standards

$F 1=\left(\frac{\text { Number of parameters that do not meet the standard }}{\text { Total number of water quality parameters }}\right) \times 100$



Fig. 1. The location of water sampling points 
F2 (Frequency): percentage of test results (in every parameter) that do not meet or have exceeded the water quality standards

$F 2=\left(\frac{\text { Number of test results that do not meet the standard }}{\text { Total number of data testing or collection }}\right) \times 100$

F3 (Amplitude): the number of values that do not meet or have exceeded the water quality standards (in percent)

a. Excursion value (Ei) calculation

For data with values exceeding the upper threshold, the excursion value was computed using the equation below:

Excursion $=$

$\frac{\text { Test results that do not meet the standard }}{\text { Quality standard }}-1$

Meanwhile, for data with values below the lower threshold, the equation below was applied:

Excursion $=\frac{\text { Quality standard }}{\text { Test results that do not meet the standard }}-1$

b. The Normalized Sum of Excursions (NSE)

$$
\begin{array}{r}
N S E=\frac{\sum(\text { Excursion })}{\text { Total } \text { number of testing }} \\
F 3=\left(\frac{N S E}{0,01 \text { NSE }+0,01}\right)
\end{array}
$$

WQI (the CCME method) $=$

$$
100-\frac{\sqrt{F 1^{2}+F 2^{2}+F 3^{2}}}{1,732}
$$

The pollutant loading capacity of Setu Babakan was computed using a mathematical formula proposed in [12]. It drew on water quality data, i.e., BOD, COD, and TSS, lake morphometry characteristics, and outlet discharge records. The lake morphometry characteristics included average depth, lake surface area, and water volume. The water volume of the lake was extracted from the bathymetric map and calculated using the equation proposed in [13] that assumes the cross-section of the lake to resemble a cone. As for the discharge at the outlet, it was measured by the buoy method. The pollutant loading capacity calculation was divided into three stages, as described below.

a. Lake Morphological and Hydrological

Characteristics

$$
\begin{gathered}
Z=100 \times \frac{V}{A} \\
\rho=\frac{Q_{0}}{V}
\end{gathered}
$$

where:

$\mathrm{Z}=$ Average depth of the lake $(\mathrm{m})$

$\mathrm{V}=$ Water volume (in millions $\mathrm{m}^{3}$ )

$\mathrm{A}=$ Water surface area (ha)

$\rho=$ Water flushing rate (1/year)

$\mathrm{Q}_{0}=$ Lake outflow discharge (in millions $\mathrm{m}^{3} /$ year) during dry years

b. Pollutant Load Allocations (Pa)

$$
[P a]_{S T D}=[P a]_{i}+[P a]_{D A S}+[P a]_{d}
$$

$[\mathrm{Pa}]_{\mathrm{STD}}=$ Maximum level of $\mathrm{Pa}$, as required by the water quality standard $\left(\mathrm{mg} \mathrm{m}^{-3}\right)$

$[\mathrm{Pa}]_{\mathrm{I}}=$ Level of $\mathrm{Pa}$, as measured during lake observation $\left(\mathrm{mg} \mathrm{m}^{-3}\right)$

$[\mathrm{Pa}]_{\text {DAS }}=\mathrm{Pa}$ from the catchment $\left(\mathrm{mg} \mathrm{m}^{-3}\right)$

$[\mathrm{Pa}]_{\mathrm{d}}=\mathrm{Pa}$ from the wastes generated by activities around the lake $\left(\mathrm{mg} \mathrm{m}^{-3}\right)$

c. $\quad \mathrm{Pa}$ Loading Capacity of the Lake Water

$$
\begin{gathered}
R=\frac{1}{\left(1+0,747 \rho^{0,507}\right)} \\
L=\frac{[P a]_{d} Z \rho}{1-R} \\
L a=L \times \frac{A}{100}
\end{gathered}
$$

where:

$\mathrm{R}=$ Internal $\mathrm{Pa}$ from lake sediments

$\mathrm{L}=\mathrm{Pa}$ of waste loading capacity per unit of lake area $\left(\mathrm{mg} / \mathrm{Pa} / \mathrm{m}^{2}\right.$ year $)$

$\mathrm{La}=$ Total $\mathrm{Pa}$ of the waste loading capacity of the lake waters $(\mathrm{Kg} \mathrm{Pa} /$ year)

\section{Results and discussion}

\subsection{Water quality}

Temperature is one of the physical parameters that are sensitive to change. Measurements in the field revealed that the temperature of Setu Babakan waters fell within the range of $26.1{ }^{\circ} \mathrm{C}$ to $30.3{ }^{\circ} \mathrm{C}$, which, according to the Governmental Regulation No. 82 of 2001, meets the quality standards for Class II water (Figure 2). Temperature is influenced by season, latitude, altitude, time, air circulation, cloud cover, and water depth [2]. All sampling points showed an increasing trend of temperatures from August until October but then decreased until February. This finding is attributable to seasonal change from the dry season (October, with a rain depth of $45 \mathrm{~mm}$ ) to the rainy season (February, with $452 \mathrm{~mm}$-deep rain). Rainfall means that more clouds are formed, and the amount and duration of sunlight entering the waters decrease, causing a decline in the water temperature.

Water temperatures at Inlet 1 and the outlet were high because there was no vegetation cover at the sampling locations, whereas the ones at Inlet 2 were low due to many vegetation covers in its surroundings. In the middle of Setu Babakan, water was collected in the morning with no objects obstructing sunlight and affecting the temperature measured. Other samples were read in the afternoon when the waters had been substantially exposed to sunlight. According to [14], water temperatures in lowlying areas closer to the equatorial line (latitude) are, on average, $29^{\circ} \mathrm{C}$, which is consistent with the temperature range identified in this study. On the contrary, in [15], waters located in highlands and far from the equator are colder, i.e., averagely $13.6{ }^{\circ} \mathrm{C}$.

where: 


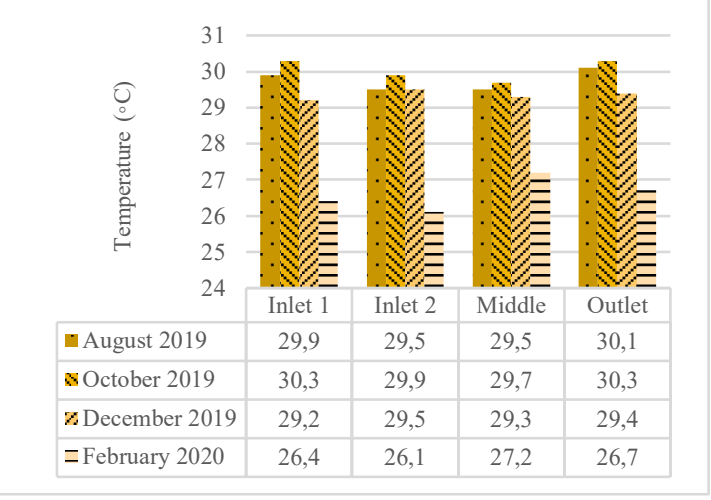

Fig. 2. Temperatures of Setu Babakan by water sample

Apart from temperatures, the field survey also measured water acidity. The readings showed that not all samples met the $\mathrm{pH}$ range of the Class II water quality standard set in the Governmental Regulation No. 82 of 2001, i.e., from 5.72 to 7.22 (Figure 3). These water samples were collected at Inlet 1 from October 2019 to February 2020 and Inlet 2 in February 2020. The water $\mathrm{pH}$ was inclined to be low in February. Acidic rainwater (low $\mathrm{pH}$ ) occurs because dissolved $\mathrm{S}, \mathrm{NO}_{2}$, and $\mathrm{CO}_{2}$ gases are present in the atmosphere [2], which may affect the $\mathrm{pH}$ values of Setu Babakan waters. It is believed to be attributed to the lower water $\mathrm{pH}$ (more acidic) in February 2020 than in August 2019.

Inlet 1 had the lowest $\mathrm{pH}$ because this location received inputs of pollutant loads in the form of organic compounds. Organic compounds will be degraded by microorganisms, producing organic acids that lower the water $\mathrm{pH}[16,17]$. The middle and outlet of the lake had higher $\mathrm{pH}$ values because they were situated far from the inflow of pollutant loads.



Fig. 3. pH Values of Setu Babakan by water sample

TSS is suspended materials that are retained or do not pass sieves with a mesh diameter of $0.45 \mu \mathrm{m}$ [2]. Based on the laboratory test results, the TSS of the water samples varied between 10 and $63 \mathrm{mg} / \mathrm{l}$. This range indicates that not all samples meet the Class II water quality standard written in the Governmental Regulation No. 82 of 2001 (Figure 4). These water samples were collected at Inlet 2, the middle, and the outlet in October 2019.

At these three sampling points, the TSS in October 2019 was high because this month marked the beginning of the dry season. Combined with evaporation, the low precipitation level in this season reduces the water input to the lake and causes its wet volume to shrink. However, with no reduction in residual solids, the concentration of insoluble substances remain [18]. The highest TSS was concentrated in the middle where flows from Inlets 1 and 2 met, creating a buildup of solid substances. Moreover, the water at this point was sampled using a boat whose movements could mix water with suspended solids. On the contrary, the lowest TSS was found at Inlet 1 because the river water that flowed through this point into Setu Babakan also had low TSS.



Fig.4. Total suspended solids of Setu Babakan by water sample

The TDS of Setu Babakan waters ranged from 135 to $204 \mathrm{mg} \mathrm{L}^{-1}$ (Figure 5). All water samples met the Class II water quality standard issued in the Governmental Regulation No. 82 of 2001, with $1000 \mathrm{mg} \mathrm{L}^{-1}$ as the upper threshold of allowable TDS in this lake..

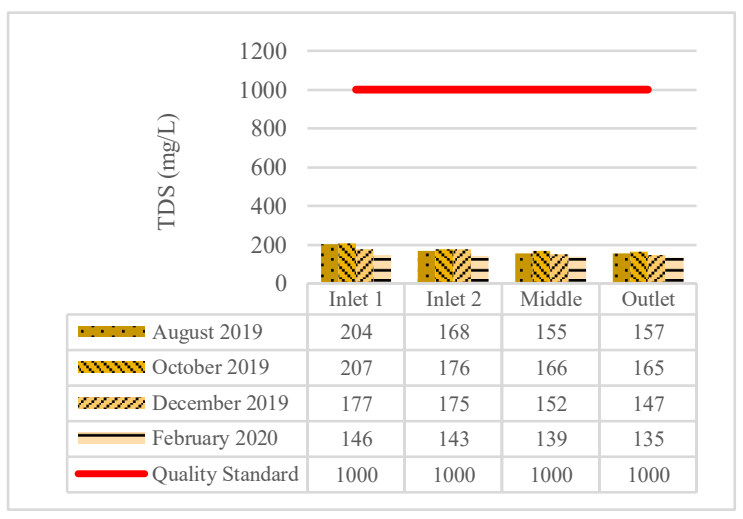

Fig. 5. Total dissolved solids of Setu Babakan by water sample

All sampling points showed that the TDS increased from August until October but then continued to decrease until February. This trend is associated with materials that are transported by surface runoff during the rainy season and accumulate in the dry season. TDS concentrations at Inlets 1 and 2 were found to be the highest because, through these points, water that carried inorganic ions flowed from the river into Setu Babakan. The middle and outlet of the lake had lower TDS concentrations because they were situated far from the inflow of pollutant loads.

Biological Oxygen Demand (BOD) levels of all water samples were in the range of $4.33 \mathrm{mg} \mathrm{L}^{-1}$ to $27.68 \mathrm{mg} \mathrm{L}^{-1}$, which, according to the Governmental Regulation No. 82 of 2001, have exceeded the maximum threshold of Class II water (Figure 6). In this range, BOD loads had contaminated Setu Babakan waters. High BOD reduces oxygen volume in the water, and microorganisms cannot 
survive in this situation. BOD concentrations in the middle and outlet of the lake were the highest. Sedimentation or accumulation of organic wastes increases the intensity of microbial decomposition that consumes available dissolved oxygen in the water; hence, high BOD [19]. Also, Inlets 1 and 2 had high BOD levels because these points continuously received inputs of organic compounds generated by industrial, domestic, and fishing activities. In the middle of Setu Babakan, the presence of these compounds increased due to tourism activities.



Fig. 6. BOD of Setu Babakan by water sample

Chemical Oxygen Demands (COD) is the amount of oxygen required to oxidize organic matters chemically through biological and non-biological degradations [2]. Based on the laboratory test results, not all samples had COD levels fitting the Class II water quality standard (Figures 7). Because of seasonal effects, COD in October was generally higher than in February. October is a dry month where the water input to the lake is limited, preventing the dilution of organic matters from taking place. COD levels of Setu Babakan waters varied between $13 \mathrm{mg} \mathrm{L}^{-1}$ and $91 \mathrm{mg} \mathrm{L}^{-1}$. Similar to BOD, the highest COD level was found at the outlet due to the buildup of organic substances.

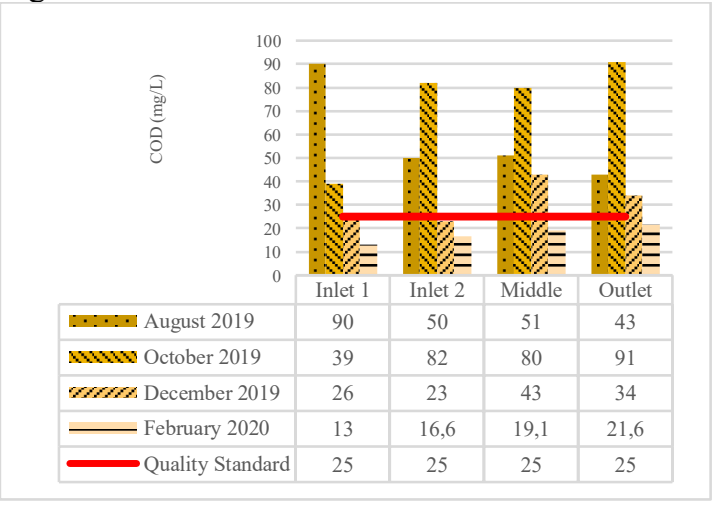

Fig. 7. COD of Setu Babakan by water sample

The laboratory test results showed that the water samples contained $0.06 \mathrm{mg} \mathrm{L}^{-1}$ to $1.14 \mathrm{mg} \mathrm{L}^{-1}$ nitrates. According to the Governmental Regulation No. 82 of 2001, the upper threshold of nitrates for a Class II water is $10 \mathrm{mg} \mathrm{L}^{-1}$, meaning that in this category the Setu Babakan waters meet this requirement (Figure 8). Agricultural fertilizers are a known source of nitrates, and this explains minute nitrate contents found in the majority of non-agricultural land use in the catchment of Setu
Babakan. In other words, the volume of agricultural wastes flowing into this lake was low. Inlets 1 and 2 were found to have the highest nitrate concentrations because these points received the droppings of farm animals carried by the river into the lake and were usually used as a fishing ground by the surrounding community. The middle and outlet had lower nitrate levels because they were situated far from the inflow of pollutant loads.

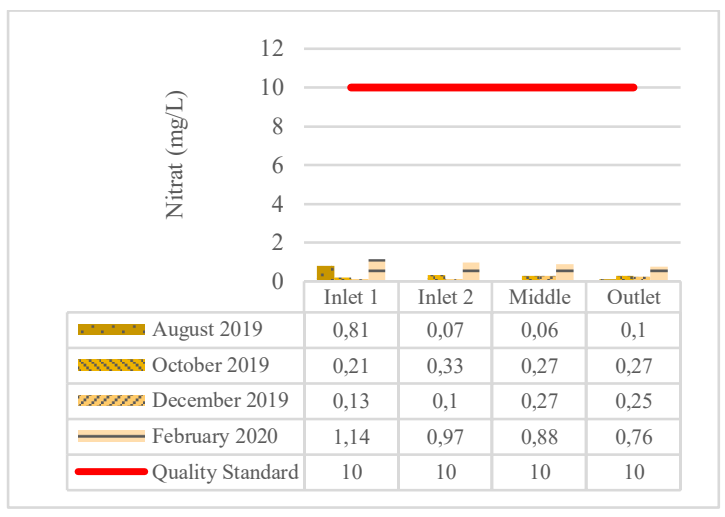

Fig. 8. Nitrate concentrations of Setu Babakan by water sample

Phosphate levels of Setu Babakan waters varied between $0.024 \mathrm{mg} \mathrm{L}^{-1}$ and $0.529 \mathrm{mg} \mathrm{L}^{-1}$. In this range, not all samples met the Class II water quality standard issued in the Governmental Regulation No. 82 of 2001, with 0.2 $\mathrm{mg} / \mathrm{l}$ as the upper threshold. Inlets 1 and 2 were the entry points of pollutant loads from the surrounding domestic activities. The overall phosphate levels decreased as rainfall increased in February, which is consistent with the theory stating that pollutant contents elevate in the dry season and rainfall determines the phosphate content of a water body [20]. Water samples of Setu Babakan showed varying concentrations of phosphate, from 0.024 to 0.529 $\mathrm{mg} / \mathrm{L}$. The highest phosphate level was detected at Inlet 1 because, at this site, domestic wastes flowed into the lake, and fishing activities were common. In contrast, the lowest level was identified at the outlet because it was far from the inflow of pollutant loads.

In the water, detergents can reduce the amount of available dissolved oxygen and disturb the life of aquatic biota. The laboratory test results showed that the water samples contained $0.0135 \mathrm{mg} \mathrm{L}^{-1}$ to $0.53 \mathrm{mg} \mathrm{L}^{-1}$ detergents. In this range, the detergent levels of most samples were still within the Class II water quality standard, with $0.2 \mathrm{mg} \mathrm{L}^{-1}$ as the upper threshold (Figure 9). The only water sample that did not meet this standard was the one collected at the lake outlet. Detergents were found the lowest at Inlet 1 and the highest at the outlet (Figure 10). Inlet 1, as the entry point of pollutant loads to the lake, had lower detergent content compared with other places. The locals often washed the boats used for waste transport and tourism activities, as well as duck paddle boats, in the middle of the lake so that the detergent levels at the outlet were inevitably high. 


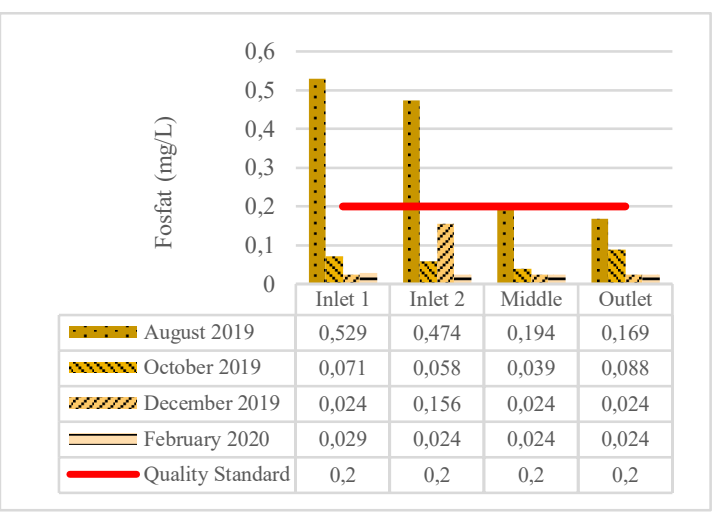

Fig. 9. Phosphate concentrations of Setu Babakan by water Sample



Fig. 10. Detergent levels of Setu Babakan by water sample

\subsection{Water quality index}

The research employed the CCME method to determine the water quality index (WQI) of Setu Babakan from several parameters, namely temperature, TDS, TSS, $\mathrm{pH}$, COD, BOD, nitrate, phosphate, and detergent. Data processing in the WQI Calculator program revealed that the water quality index at Inlet 1 , Inlet 2 , the middle, and the outlet scored 64, 60, 68.8, and 64, respectively (Table 2 ). Based on these values, the water quality index of Setu Babakan for tourism or recreation purposes was categorized into two, namely fair (65-79) and marginal (45-64).

Table 2. The water quality index of setu babakan based on the CCME Method

\begin{tabular}{ccccc}
\hline Stations & Inlet 1 & Inlet 2 & Middle & Outlet \\
\hline F1 & 44.4 & 55.6 & 33.3 & 44.4 \\
\hline F2 & 30.6 & 25 & 22.2 & 25 \\
\hline F3 & 31.2 & 32.9 & 36.2 & 35.9 \\
\hline $\begin{array}{c}\text { CCME } \\
\text { WQI }\end{array}$ & 64 & 60 & 68.8 & 64 \\
\hline $\begin{array}{c}\text { WQI } \\
\text { Category }\end{array}$ & Marginal & Marginal & Fair & Marginal \\
\hline
\end{tabular}

The water quality index at the middle was fair because only three parameters were above their allowable presence in Class II water, namely TSS, BOD, and COD. Meanwhile, the other samples were marginal because 4-5 parameters had exceeded the quality standard, namely $\mathrm{pH}$, TSS, BOD, COD, and phosphate. Inlets 1 and 2 had a marginal water quality index because they served as the entry points of wastes where, at the same time, many human activities like fishing took place. As for the outlet, the same marginal quality was caused by the accumulation of contaminants. The BOD and COD of all samples had exceeded the Class II water quality standard as a result of domestic and non-domestic wastes flowing into Setu Babakan. Besides, domestic wastes that were disposed of directly into the river or drainage channels were untreated.

\subsection{Pollutant loading capacity}

The pollutant loading capacity of Setu Babakan was calculated from TSS, BOD, and COD using the guidelines described in [12]. These three parameters are commonly used as indicators of pollution due to the presence of domestic wastes in the water, which matched residential buildings that cover most of the lake catchment. The loading capacity represents the maximum concentrations of pollutants contributing to TSS, BOD, and COD that Setu Babakan can accommodate.

Table 3 shows that the loading capacity was negative, meaning that Setu Babakan can no longer accommodate contaminants from domestic wastes, as represented by TSS, BOD, and COD levels. This negative value is associated with the exceeded thresholds in the water quality standard. Low volume $\left(79269 \mathrm{~m}^{3}\right)$ and shallow depth $(0.42 \mathrm{~m})$ are also believed to be the underlying causes. Such a high amount of domestic waste was because settlements occupied a large proportion of the catchment area, or in other words, domestic activities substantially contributed to the TSS, BOD, and COD at Setu Babakan, through river flows or surface runoffs.

Table 3. Pollutant loading capacity of Setu Babakan

\begin{tabular}{cccc}
\hline & TSS & BOD & COD \\
\hline $\begin{array}{c}\text { Kg } \\
\text { Pa/year }\end{array}$ & -129357 & -273913 & -280543 \\
\hline
\end{tabular}

\section{Conclusion}

Several water quality parameters of Setu Babakan have exceeded the Class II water quality standard issued in the Governmental Regulation No. 82 of 2001, namely pH, TSS, BOD, COD, phosphate, and detergent. Based on the CCME method, the water quality index of this lake is categorically fair (as evident from the water sample taken at the middle) and marginal (samples at Inlet 1, Inlet 2, and the outlet). The pollutant loading capacity for TSS, BOD, and COD parameters has been exceeded.

The authors would like to thank Universitas Gadjah Mada for funding this research through the Thesis Recognition Grant (Hibah Rekognisi Tugas Akhir) in the fiscal year 2020. This support was significantly helpful in the research and completion of the thesis. The authors would also like to acknowledge the 
Faculty of Geography UGM for providing the opportunity to conduct this research.

\section{References}

1. Indarto, Hidrologi: Dasar Teori dan Contoh Aplikasi Model Hidrologi, First Edition. Bumi Aksara, Jakarta (2010) [in Bahasa Indonesia]

2. H. Effendi, Telaah Kualitas Air Bagi Pengelolaan Sumber Daya dan Lingkungan Perairan. Kanisius, Yogyakarta (2003) [in Bahasa Indonesia]

3. Lukman, Kondisi Perikanan Perairan Situ dan Studi Empat Situ di Wilayah Bogor Lukman, in Prosiding Seminar Nasional Ikan VI, 371-379, (2009) [in Bahasa Indonesia]

4. U. Suriawiria, Mikrobiologi AIR. Penerbit Alumni, Bandung, (2008) [in Bahasa Indonesia]

5. F.F. Awaludin, Permasalahan Pencemaran dan Penyediaan Air Bersih di Perkotaan dan Permasalahan Pencemaran dan Penyediaan Air Bersih di Perkotaan dan Pedesaan, Undergraduate Thesis, Fakultas Teknologi Industri, Institut Teknologi Bandung, Bandung (2015) [in Bahasa Indonesia]

6. Ş. Şener, A. Davraz, R. Karagüzel, Environ. Earth Sci., 70,6:2527-2544 (2013)

7. [7] S. Bahri, F. Ramadhan, I. Reihannisa, J. Ilm. Biol., 3,1:16-22 (2015) [in Bahasa Indonesia]

8. [8] R. Maniagasi, S.S. Tumembouw, Y. Mundeng, J. Budid. Perair., 1,2:29-37 (2013) [in Bahasa Indonesia]

9. [9] Anonim, Peraturan Pemerintah Nomor 82 Tahun 2001 tentang Pengelolaan Kualitas Air dan Pengendalian Pencemaran Air. Sekretariat Negara, Jakarta, (2001) [in Bahasa Indonesia]

10. BSN, SNI 6989. 57: tentang Metode Pengambilan Contoh Air Permukaan, BSN, Jakarta, (2008) [in Bahasa Indonesia]

11. CCME, CCME Water Quality Index user's manual 2017 Update. Winnipeg, (2017)

12. Anonim, Peraturan Menteri Negara Lingkungan Hidup Nomor 28 Tahun 2009, tentang Daya Tampung Beban Pencemaran Air Danau dan / atau Waduk, Sekretariat Negara, Jakarta, (2009) [in Bahasa Indonesia]

13. L. Hakanson, A Manual of Lake Morphometry. Springer-Verlag Berlin Heidelberg, New York, (1981)

14. H.F. Gafri, F.M. Zukim, F.M. Zeeda, N. Affan, A.H. Sulaiman, S. Norasih, A Study Water Environ. Qual., 29, 51-65 (2018)

15. R. Damo, P. Icka, Pol. J. Environ. Stud., 22,4:, 10451051 (2013)

16. Yazwar, Keanekaragaman Plankton dan Keterkaitannya dengan Kualitas Air di Parapat Danau Toba, Thesis, Sekolah Pasca Sarjana, Universitas Sumatera Utara, (2008) [in Bahasa Indonesia]

17. P. Paramita, M. Shovitri, N.D. Kuswytasari, J. Sains dan Seni ITS, 1:3-6 (2012) [in Bahasa Indonesia]

18.F.A. Rasyadi, Kajian Daya Tampung Beban Pencemaran Danau Merdada Kecamatan Batur, Kabupaten Banjarnegara, Fakultas Geografi, Universitas Gadjah Mada, Yogyakarta, (2016) [in Bahasa Indonesia]

19. D. Elfidasari, N. Noriko, Y. Effendi, R.L. Puspitasari, Al-Azhar Indones. Seri Sains dan Teknol., 3,2:104 112 (2015) [in Bahasa Indonesia]

20. G. Boge, N. Jean, J.L. Jamet, D. Jamet, S. Richard, Mar. Environ. Res., 61,1:1-18 (2006), doi: 10.1016/j.marenvres.2005.03.002. 